О. В. Кривов’яз, Ю. О. Томашевська, С. О. Кривов’яз, І. К. Щерба Вінницький національний медичний університет імені М. I. Пирогова

\title{
РОЗВИТОК СПЕЦІАЛЬНИХ (ФАХОВИХ) КОМПЕТЕНТНОСТЕЙ ЯК ШЛЯХ ДО ПОКРАЩЕННЯ ЯКОСТІ ПРАКТИЧНОЇ ПІДГОТОВКИ СТУДЕНТІВ
}

\author{
O. V. Kryvoviaz, Iu. O. Tomashevska, S. O. Kryvoviaz, I. K. Shcherba \\ M. Pyrohov Vinnytsia National Medical University
}

\section{DEVELOPMENT OF SPECIAL (PROFESSIONAL) COMPETENCE AS A WAY TO IMPROVING QUALITY OF STUDENTS' PRACTICAL TRAINING}

\begin{abstract}
Мета роботи - визначення технологічної операції, здійснення якої спричиняє найбільші труднощі та відстеження динаміки показників її виконання студентами в процесі навчання на III-V курсах фармацевтичного факультету Вінницького національного медичного університету імені М. І. Пирогова, а також розробка плану заходів по удосконаленню спеціальних (фахових) компетентностей при практичній підготовці студентів.

Основна частина. У дослідженні брали участь студенти фармацевтичного факультету спеціальностей “Фармація” “ “Клінічна фармація” денної форми навчання, під час їх навчання на III, IV та V курсах. Дослідження включало два послідовних етапи: I - опитування студентів за анкетою та аналіз ними технологічних схем виготовлення екстемпоральних лікарських засобів 3 метою визначення технологічної операції, здійснення якої викликає найбільші труднощі; II етап - виконання операції дозування з подальшим визначенням похибки зважування за формулою. В результаті проведеного дослідження було встановлено, що операцією, виконання якої викликає найбільші труднощі, для більшості студентів (38,89 \%) є дозування за масою з використанням як ручних, так і тарирних терезів.

Висновок. Перевірка динаміки засвоєння цієї навички студентами в різні періоди навчання показала прогрес в опануванні уміння дозування за масою та покращення практичної підготовки студентів, чому сприяє інтеграція самостійної теоретичної підготовки з відпрацюванням уміння відважування речовин під керівництвом викладача.
\end{abstract}

Ключові слова: спеціальні (фахові) компетентності; дозування за масою; практична підготовка студентів.

The aim of the work - to define a technological operation, the implementation of which caused the greatest difficulties, tracking the dynamics of its performance by students in the process of training at the III-V courses of the Pharmaceutical Faculty of M. Pyrohov Vinnytsia National Medical University, as well as developing a plan of measures for the improvement of special (professional) competencies in practical training of students.

The main body. The study involved students of the pharmaceutical faculty of the specialties of Pharmacy and Clinical Pharmacy of full-time education, during their training in III, IV and V courses. The study included two consecutive stages: I - survey of students on the questionnaire and analysis of their technological schemes for the manufacture of extemporal drugs in order to identify the technological operation, the implementation of which causes the greatest difficulty; II stage - execution of the operation of the dosage with the subsequent determination of the error of weighing by the formula. As a result of the study, it was found that the operation, the execution of which causes the greatest difficulty, for most students (38.89\%), is the dosage by weight, using both manual and tare scales.

Conclusion. The examination of the dynamics of the learning of this skill by students in different periods of study has shown progress in mastering the ability to dosing by weight and improving the practical training of students, as facilitated by the integration of independent theoretical training with the development of the ability to weigh the substances under the direction of the teacher.

Key words: special (professional) competencies; dosing by mass; practical training of students.

Вступ. У вищому фармацевтичному (медичному) навчальному закладі першочерговим завданням $€$ високий рівень набуття практичних навичок майбутніми спеціалістами галузі фармації при вивченні дисциплін циклу професійної підготовки, зокрема технологічного комплексу.
У процесі навчання студенти фармацевтичного факультету зустрічаються з певними труднощами набуття спеціальних (фахових) компетентностей. Основним шляхом подолання цієї проблеми доцільно вважати проходження навчальних (пропедевтичних) та, особливо, виробничих практик, під час

() О. В. Кривов’яз, Ю. О. Томашевська, С. О. Кривов’яз, І. К. Щерба 
яких відбувається удосконалення виконання професійних технологічних операцій на основі набутих теоретичних знань з дисциплін. Проходження студентами практики $є$ визначальним у структурі пізнавальної діяльності майбутнього фахівця-провізора, направлене на набуття мотиваційної, когнітивної та операційної складових професійного росту. Слід також відзначити, що практика сприяє розвитку самостійного виконання виробничих функцій в умовах, наближених до асистентської кімнати аптеки, підвищує здатність до прийняття рішень, зокрема в питаннях вибору ваговимірювальних приладів та допоміжних матеріалів, надає можливість раціонального вибору і обгрунтування здійснення технологічних операцій тощо.

Принципи раціональної організації навчального процесу закладені в нормативних документах, зокрема в Стандарті вищої освіти України другого (магістерського) рівня вищої освіти галузі знань 22 “Охорона здоров’я” спеціальності 226 “Фармація”. Особливу увагу привертає спеціальна (фахова) компетентність “КФ 3. Здатність організовувати виробничу діяльність аптек щодо виготовлення лікарських препаратів у різних лікарських формах за рецептами лікарів і замовленнями лікувальних закладів, включаючи обгрунтування технології та вибір допоміжних матеріалів відповідно до правил Належної аптечної практики (GPP)”, яка передбачає вимірюваний результат навчання у формі вибору раціональної технології, виготовлення лікарських засобів у різних лікарських формах за рецептами лікарів і замовленнями лікувальних закладів, оформлення їх до відпуску; виконання технологічних операцій: відважувати, відмірювати, дозувати різноманітні лікарські засоби за масою, об’ємом тощо.

Мета роботи - визначення технологічної операції, здійснення якої спричиняє найбільші труднощі, відстеження динаміки показників її виконання студентами в процесі навчання на III-V курсах фармацевтичного факультету Вінницького національного медичного університету імені М. І. Пирогова, а також розробка плану заходів по удосконаленню спеціальних (фахових) компетентностей при практичній підготовці студентів.

Основна частина. В дослідженні брали участь студенти фармацевтичного факультету спеціальностей “Фармація” і “Клінічна фармація” денної форми навчання, під час їх навчання на III, IV та V курсах, тобто до, в процесі та після закінчення вивчення аптечної технології лікарських засобів
(АТЛ), проходження пропедевтичної та виробничої практики з АТЛ, виробничої практики зі спеціалізації (технології ліків). Дослідження включало два послідовних етапи: I - опитування студентів за анкетою та аналіз ними технологічних схем виготовлення екстемпоральних лікарських засобів з метою визначення технологічної операції, здійснення якої викликає найбільші труднощі; II етап виконання операції дозування з подальшим визначенням похибки зважування за формулою.

Дизайн дослідження передбачав два послідовних етапи: I - опитування студентів за розробленою анкетою (рис. 1) та аналіз ними технологічних схем виготовлення екстемпоральних лікарських засобів з метою визначення технологічної операції, здійснення якої викликає найбільші труднощі; II етап виконання операції дозування за масою 0,2 г натрію хлориду на ручних терезах ВР-1; 1,2 г - на ВР-5; 6,0 г - на ВР-20; 25,0 г - на ВР-100; 200,0 г олії соняшникової на технічних терезах ВКТ-1000 з подальшим визначенням похибки зважування $\Delta m$ за розробленою формулою 1 при перевірці точності дозованої маси речовини за допомогою ваг лабораторних загального призначення електронних TBE-0,3-0,005:

$$
\Delta m=m_{1}-m_{2},
$$

де $\Delta m$ - похибка зважування, г;

$m_{1}$ - маса речовини, зваженої на ручних або технічних терезах, г;

$m_{2}$ - маса речовини, визначена при проведенні контрольного зважування на вагах лабораторних загального призначення електронних ТВE-0,3-0,005, г.

Після цього здійснювали порівняння отриманого значення $\Delta m$ з допустимою похибкою при зважуванні певної маси речовини на відповідних ручних або технічних терезах $\mathrm{S}_{\text {абс. }}$, вказаною в таблиці метрологічних характеристик ручних і тарних ваг.

У випадку, коли виконувалась умова $\Delta m \leq \mathrm{S}_{\text {абс., }}$, робили висновок про задовільний результат дозування. Якщо $\Delta m>\mathrm{S}_{\text {абс. }}$, то технологічна операція була здійснена неякісно. При цьому, чим більшою була різниця між $\Delta m$ та $\mathrm{S}_{\text {абс. }}$ тим в меншому ступені було володіння студентом навичкою.

Таким чином, на І етапі дослідження було роздано анкети 124 студентам фармацевтичного факультету спеціальності “Фармація”, з них 34 - іноземних 3 російською та англійською мовами навчання.

Дані опитування, наведені на рисунку 2, показали, що переважна більшість студентів вважає уміння “відважувати, відмірювати та дозувати різноманітні лікарські засоби за масою та об’ ємом згідно $з$ 


\section{Анкета}

\section{Шановні студенти!}

Оцініть за 10-бальною шкалою наведені згідно з Додатком до Стандарту вищої освіти України другого (магістерського) рівня вищої освіти галузі знань 22 “Охорона здоров’я” спеціальності 226 “Фармація” умінь фахові компетентності “КФ 3. Здатність організовувати виробничу діяльність аптек щодо виготовлення лікарських препаратів у різних лікарських формах за рецептами лікарів і замовленнями лікувальних закладів, включаючи обгрунтування технології та вибір допоміжних матеріалів відповідно до правил Належної аптечної практики (GPP)”.

\begin{tabular}{|c|c|c|}
\hline № & Уміння & Бальна оцінка* \\
\hline 1 & $\begin{array}{l}\text { Характеризувати лікарські форми за типами дисперсних систем, способом вживання, } \\
\text { місцем призначення, агрегатним станом, враховуючи фізико-хімічні властивості діючих } \\
\text { та допоміжних речовин }\end{array}$ & \\
\hline 2 & $\begin{array}{l}\text { Визначити у прописі та усувати несумісності біологічно активних речовин та лікарської } \\
\text { рослинної сировини: фізичну, хімічну та фізико-хімічну, фармакологічну }\end{array}$ & \\
\hline 3 & $\begin{array}{l}\text { Перевірити i, якщо необхідно, виправляти разові, добові і курсові дози отруйних, нар- } \\
\text { котичних, сильнодіючих речовин та норми відпуску наркотичних і прирівняних до них } \\
\text { речовин, враховуючи індивідуальні особливості людини (вік, маса тіла та ін.) }\end{array}$ & \\
\hline 4 & $\begin{array}{l}\text { Відважувати, відмірювати та дозувати різноманітні лікарські засоби за масою та об’ємом } \\
\text { згідно з прописом }\end{array}$ & \\
\hline 5 & $\begin{array}{l}\text { Готувати екстрагенти необхідної концентрації, користуючись різними розрахунковими } \\
\text { методами }\end{array}$ & \\
\hline 6 & $\begin{array}{l}\text { Стабілізувати фармацевтичні препарати, враховуючи біологічні, фізико-хімічні, техно- } \\
\text { логічні властивості діючих і допоміжних речовин, використовуючи необхідні реактиви }\end{array}$ & \\
\hline 7 & $\begin{array}{l}\text { Готувати різноманітні лікарські форми та внутрішньоаптечні заготовки з лікарських і до- } \\
\text { поміжних речовин: в технологічних схемах приготування екстемпоральних лікарських } \\
\text { форм, що додаються, позначте операцію, виконання якої викликає найбільші труднощі }\end{array}$ & \\
\hline 8 & $\begin{array}{l}\text { Здійснювати стерилізацію лікарських форм, враховуючи фізико-хімічні властивості та } \\
\text { стабільність лікарських речовин }\end{array}$ & \\
\hline 9 & $\begin{array}{l}\text { Оформляти до відпуску виготовлені лікарські засоби з отруйними, наркотичними та при- } \\
\text { рівняними до них речовинами }\end{array}$ & \\
\hline 10 & Оформляти паспорти письмового контролю на всі виготовлені лікарські засоби & \\
\hline
\end{tabular}

Примітка. *0 балів - виконання уміння не викликає жодних труднощів; 10 балів - виконання уміння викликає найбільші труднощі.

Рис. 1. Форма анкети.

прописом” таким, виконання якого викликає найбільше труднощів.

3 метою деталізації уміння “готувати різноманітні лікарські форми та внутрішньоаптечні заготовки 3 лікарських і допоміжних речовин” студентам надавалися для детального аналізу 19 технологічних схем приготування екстемпоральних лікарських форм. Було визначено, що операцією, виконання якої викликає найбільші труднощі, для більшості студентів (38,89 \%) є дозування за масою з використанням як ручних, так і тарирних терезів.

Отже, надалі перевіряли динаміку засвоєння саме цієї навички студентами в різні періоди навчання:

1 - на початку V семестру при вивченні теми “Дозування” дисципліни “Аптечна технологія лікарських засобів”;

2 - складання заліку з практичних навичок наприкінці V семестру;

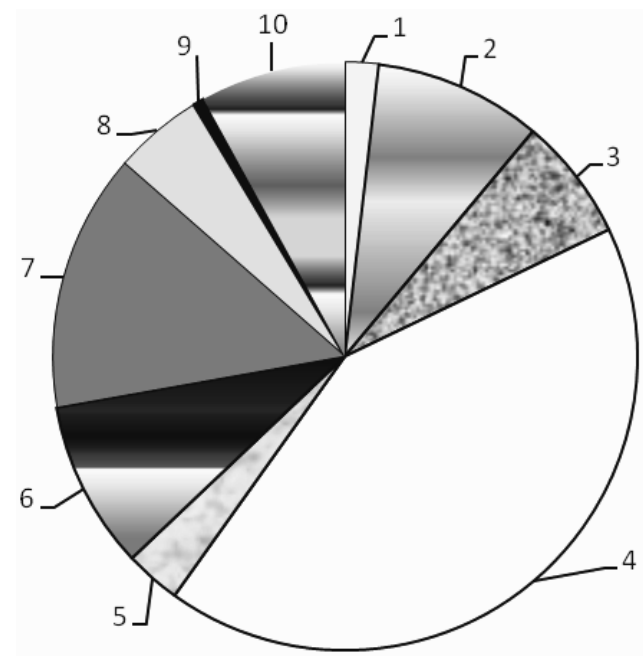

Рис. 2. Результати анкетування з визначення уміння, виконання якого викликає найбільше труднощів (позначення 1-10 див. на рис. 1). 
3 - під час проходження пропедевтичної практики з АТЛ (тема “Дозування”);

4 - складання заліку з практичних навичок наприкінці VI семестру (перед іспитом з АТЛЗ) та диференційного заліку з пропедевтичної практики 3 АТЛ;

5 - під час проходження виробничої практики 3 АТЛЗ (тема “Дозування”);

6 - складання диференційного заліку з виробничої практики з АТЛз;

7 - під час проходження виробничої практики зі спеціалізації (технологія ліків) (тема “Дозування”);

8 - складання диференційного заліку з виробничої практики зі спеціалізації (технологія ліків).
Розраховували похибку зважування $\Delta m$ (формула 1) та порівнювали її з допустимою похибкою $\mathrm{S}_{\text {абс. }}$ роблячи висновок про якість виконання практичної навички $\left(\Delta m \leq \mathrm{S}_{\text {абс. }}\right.$ - “задовільно”, $\Delta m>\mathrm{S}_{\text {абс. }}-$ “незадовільно”).

Динаміку виконання студентами уміння “відважувати, відмірювати та дозувати різноманітні лікарські засоби за масою та об’ємом згідно з прописом” у процесі навчання визначали, розраховуючи кількість осіб, які задовільно виконали навичку на кожному з періодів навчання (табл. 1).

Необхідно зауважити, що не було виявлено жодного студента, в якого не відмічався прогрес в опануванні досліджуваної навички дозування за масою.

Таблиця 1. Динаміка виконання студентами уміння “відважувати, відмірювати та дозувати різноманітні лікарські засоби за масою та об’ємом згідно з прописом” у процесі навчання

\begin{tabular}{|c|c|c|c|c|c|c|c|c|c|c|c|c|}
\hline \multirow{3}{*}{$\begin{array}{c}\text { Період } \\
\text { навчання }\end{array}$} & \multirow{2}{*}{\multicolumn{2}{|c|}{\begin{tabular}{|c|}
$\begin{array}{c}\text { Загальна кількість } \\
\text { студентів }\end{array}$ \\
\end{tabular}}} & \multicolumn{10}{|c|}{ Вид терезів } \\
\hline & & & \multicolumn{2}{|c|}{ BP-1 } & \multicolumn{2}{|c|}{ BP-5 } & \multicolumn{2}{|c|}{ BP-20 } & \multicolumn{2}{|c|}{ BP-100 } & \multicolumn{2}{|c|}{ BKT-1000 } \\
\hline & $\begin{array}{l}\text { абс. } \\
\text { чол }\end{array}$ & $\begin{array}{c}\text { відн. } \\
\%\end{array}$ & $\begin{array}{l}\text { абс. } \\
\text { чол. }\end{array}$ & $\begin{array}{c}\text { відн. } \\
\%\end{array}$ & $\begin{array}{l}\text { абс. } \\
\text { чол. }\end{array}$ & $\begin{array}{c}\text { відн. } \\
\%\end{array}$ & $\begin{array}{l}\text { абс. } \\
\text { чол. }\end{array}$ & $\begin{array}{c}\text { відн. } \\
\%\end{array}$ & $\begin{array}{l}\text { абс. } \\
\text { чол. }\end{array}$ & $\begin{array}{c}\text { відн. } \\
\%\end{array}$ & $\begin{array}{l}\text { абс. } \\
\text { чол. }\end{array}$ & $\begin{array}{c}\text { відн. } \\
\%\end{array}$ \\
\hline 1 & 124 & 100 & 15 & 12,10 & 17 & 13,71 & 22 & 17,74 & 21 & 16,94 & 8 & 6,45 \\
\hline 2 & & & 42 & 33,87 & 35 & 28,23 & 53 & 42,74 & 48 & 38,71 & 31 & 25,00 \\
\hline 3 & & & 45 & 36,29 & 39 & 31,45 & 57 & 45,97 & 50 & 40,32 & 34 & 27,42 \\
\hline 4 & & & 78 & 62,90 & 75 & 60,48 & 92 & 74,19 & 81 & 65,32 & 84 & 67,74 \\
\hline 5 & & & 80 & 64,52 & 76 & 61,29 & 96 & 77,42 & 82 & 66,13 & 84 & 67,74 \\
\hline 6 & & & 105 & 84,68 & 97 & 78,23 & 108 & 87,10 & 100 & 80,65 & 94 & 75,81 \\
\hline 7 & & & 110 & 88,71 & 116 & 93,55 & 118 & 95,16 & 109 & 87,90 & 104 & 83,87 \\
\hline 8 & & & 113 & 91,13 & 122 & 98,39 & 122 & 98,39 & 119 & 95,97 & 115 & 92,74 \\
\hline
\end{tabular}

Висновки. Отримані в процесі дослідження результати вказують на те, що виконання деяких практичних навичок викликає труднощі у студентів. Надзвичайно гостро постає проблема виконання навички дозування лікарських та допоміжних речовин різної консистенції за масою з використанням ручних та технічних терезів, оскільки ця практична навичка є основою більшості технологічних процесів виготовлення лікарських засобів.

Проходження студентами пропедевтичної практики з аптечної технології ліків, виробничої практики 3 аптечної технології лікарських засобів та виробничої практики зі спеціалізації (технології ліків) сприяє позитивній динаміці у виконанні практичних навичок (зокрема дозування за масою), що виражається у збільшенні кількості студентів, які задовільно їх здійснюють.

Покращенню практичної підготовки студентів сприяє інтеграція самостійної теоретичної підготовки з відпрацюванням уміння відважування ре- човин під керівництвом викладача, що може бути досягнуто такими методами, як:

- ретельний підбір баз практики з урахуванням специфіки виконання практичних навичок у відповідності з програмою;

- створення навчальних відеороликів, що містять детальний поетапний інструктаж виконання певних умінь;

- розробка навчальних карт здійснення наведених у Додатку до Стандарту вищої освіти України другого (магістерського) рівня вищої освіти галузі знань 22 “Охорона здоров’я” спеціальності 226 “Фармація” умінь фахової компетентності “КФ 3. Здатність організовувати виробничу діяльність аптек щодо виготовлення лікарських препаратів у різних лікарських формах за рецептами лікарів і замовленнями лікувальних закладів, включаючи обгрунтування технології та вибір допоміжних матеріалів відповідно до правил Належної аптечної практики (GPP)”. 


\section{Список літератури}

1. Стандарт “Настанова “Вимоги до виготовлення нестерильних лікарських засобів в умовах аптеки. СТ-Н МОЗУ 42-4.5:2015””' [Електронний ресурс]. - Режим доступу : http://www.moz.gov.ua/ua/portal/ dn_20150701_0398.html.

2. Стандарт “Настанова “Вимоги до виготовлення стерильних лікарських засобів в умовах аптеки. СТ-Н МОЗУ 42-4.6:2015”,” [Електронний ресурс]. - Режим доступу : http://www.moz.gov.ua/ua/portal/dn_20150701_0398.html.

3. Технологія ліків. Навчально-методичний посібник / [О. І. Тихонов, П. А. Логвін, С. О. Тихонова та ін.] ; за ред. О. І. Тихонова. - Х. : НФаУ; Оригінал, 2009. - 432 с.

\section{References}

1. Standart "Nastanova "Vymohy do vyhotovlennia nesterylnykh likarskykh zasobiv v umovakh apteky. ST-N MOZU 42-4.5:2015" " [Standard “Instruction "Requirements for the manufacture of non-sterile medicines in pharmacy conditions"”]. Retrieved from: http:// www.moz.gov.ua/ua/portal/dn_20150701_0398.html [in Ukrainian].

2. Standart "Nastanova "Vymohy do vyhotovlennia sterylnykh likarskykh zasobiv v umovakh apteky. ST-N MOZU 42-4.6:2015" " [Standard "Instruction "Requirements for the manufacture of sterile medicinal products under pharmacy conditions" "]. Retrieved from: http://www.moz. gov.ua/ua/portal/dn_20150701_0398.html [in Ukrainian].
4. Тихонов О. І. Аптечна технологія ліків : підручник для студ. фарм. ф-тів ВМНЗ України III-IV рівнів акредитації / О. І. Тихонов, Т. Г. Ярних ; за ред. О. І. Тихонова. - 4-те вид., випр. та допов. - Вінниця : Нова Книга, 2016. - 536 с., іл.

5. Стандарт вищої освіти України другого (магістерського) рівня вищої освіти галузі знань 22 “Охорона здоров’я” спеціальності 226 “Фармація” [Електронний ресурс]. - Режим доступу : http://www.vnmu.edu.ua.

3. Tykhonov, O.I., Lohvin, P.A., Tykhonova, S.O., Mazulin, O.V., Yarnykh, T.H., ... Shpychak, O.S. (2009). Tekhnolohiia likiv [Drug technology]. Kharkiv: NFaU [in Ukrainian].

4. Tykhonov, O.I., \& Yarnykh, T.H. (2016). Aptechna tekhnolohiia likiv [Pharmacy drug technology]. Vinnytsia: Nova Knyha [in Ukrainian].

5. Standart vyshchoi osvity Ukrainy druhoho (mahisterskoho) rivnia vyshchoi osvity haluzi znan 22 "okhorona zdorovia" spetsialnosti 226 "Farmatsiia" [The standard of higher education of Ukraine for the second (masters) level of higher education in the field of knowledge 22 "Health Care” specialty 226 "Pharmacy"]. Retrieved from: http://www.vnmu.edu.ua [in Ukrainian].

Електронна адреса для листування: i.nurmetova@gmail.com 